Article

\title{
Assessing the Hydrologic Performance of a Green Roof Retrofitting Scenario for a Small Urban Catchment
}

\author{
Anna Palla *, Ilaria Gnecco (iD) and Paolo La Barbera \\ Department of Civil, Chemical and Environmental Engineering, University of Genova, Genoa 16145, Italy; \\ ilaria.gnecco@unige.it (I.G.); paolo.labarbera@unige.it (P.L.B.) \\ * Correspondence: anna.palla@unige.it; Tel.: +39-(010)-353-2301
}

Received: 11 July 2018; Accepted: 6 August 2018; Published: 8 August 2018

\begin{abstract}
In an existing urban environment, retrofitting low impact development (LID) solutions can provide an opportunity to address flooding and water quality problems. Taking into account the need to effectively estimate the impact of vegetated LIDs, particular attention has recently been given on the evapotranspiration (ET) process that is responsible for the restoring of green roof water-holding capacity. The present study aims to develop a methodological approach to estimate the actual ET as climate input data in the United States Environmental Protection Agency (EPA) Storm Water Management Model (SWMM) continuous simulation. The proposed approach is calibrated on a single green roof installation based on one-minute continuous simulations over 26 years of climate records. Then the calibrated methodological approach has been implemented to perform continuous simulation of a small urban catchment retrofitted with green roofs. Based on simulation results, the peak and volume reduction rate evaluated for the 1433 rainfall events are equal to 0.3 on average (with maximum values of 0.96 for peak and 0.86 for volume). In general, the adopted methodology indicates that the actual ET estimate is needed to suitably assess the hydrologic performance of vegetated LIDs mainly concerning the volume reduction index; furthermore, the methodology can be easily replicated for other vegetated LID applications.
\end{abstract}

Keywords: detention; evapotranspiration; green roof; hydrologic modelling; retention; source control; Storm Water Management Model (SWMM)

\section{Introduction}

In the last few decades, water quality and quantity issues related to the urban environment pose multiple challenges involving many actors such as researchers, local and regional public authorities, and citizens. In order to address the need to control and limit storm water runoff, low impact development (LID) principles and applications represent the new approach to storm water management. LID solutions are designed to mimic pre-development hydrologic conditions thus promoting storage, infiltration and evapotranspiration (ET) processes. Storm water infiltration systems, rain gardens, green roofs and permeable pavements are included among LIDs.

Referring to the single installation scale, the performance of LIDs as runoff source control measures is well documented in the literature (e.g., [1]). Several experimental studies, carried out at both the pilot and full scales, demonstrate that LIDs contribute to reducing the runoff volume and peak flow rate. As an example, the storm water volume retention observed for green roofs varies between $12 \%$ and $75 \%$ at the event scale [2] while the peak reduction ranges between 60 and $80 \%$ (e.g., [3]).

By considering the hydrologic performance of LIDs, it follows that, in an existing urban environment, retrofitting LID solutions provide an opportunity to mitigate flooding and water quality 
problems. Palla and Gnecco [4] investigated the hydrological response of a retrofitted urban catchment based on simulations at the event scale: modelling results pointed out that the effectiveness of LID solutions requires a minimum land-use conversion. Since the installation of LIDs at the catchment scale is still scarce (e.g., [5,6]), the effectiveness of LIDs to control storm water runoff at the urban catchment scale is an open debate among researchers.

Among LIDs, particular attention has been posed on the vegetated systems since vegetation plays a crucial role in the urban environment: promoting the evapotranspiration process, limiting the urban heat island effect, increasing biodiversity, and achieving aesthetic and recreational objectives.

By considering the multiple benefits associated with vegetated LID systems, several studies (e.g., $[2,7,8])$ have been recently focused on the impact of ET on the retention performance of green roofs since ET is a keystone in continuous simulations. Both experimental and modelling results confirm that the characteristics of green roofs (in term of field capacity) determine the retention capacity, while the ET process is responsible for restoring the water-holding capacity of green roofs [9].

Based on the above considerations, there is a need to effectively estimate the impact of LIDs on the hydrologic response of an urban catchment not only referring to design storm or synthetic hyetographs at the assigned return period, but also to continuous simulations including the precipitation regime features (e.g., [10]) as well as the varying soil moisture conditions (e.g., [11]).

In this framework, the main objective of this paper is to investigate the role of vegetated LIDs in storm water runoff mitigation at the urban catchment scale by analysing the continuous simulation results. The first specific objective is to define a methodological approach to estimate the actual ET as climate input data in continuous simulation; with this aim, the proposed approach is tested on a single green roof over at least 20-years of precipitation records. The second specific objective is to examine the impact of the actual ET vs. the potential ET in reducing the hydrologic performance of a vegetated LID system; for these purposes, the results of the continuous simulation carried out for the single green roof are analysed by means of hydrologic performance indexes on seasonal and event basis. The final specific objective is to identify the hydrologic variables that significantly affect the storm water runoff mitigation provided by vegetated LIDs; for this purpose, the proposed methodological approach has been implemented to perform continuous simulation at high spatial and time resolution scales of a small urban catchment retrofitted with green roofs.

\section{Materials and Methods}

A methodological approach is proposed to define a numerical framework that can be applied to any vegetated LID systems to properly account for the actual ET in continuous simulations. The United States Environmental Protection Agency (EPA) Storm Water Management Model (SWMM), which is one of the most commonly used softwares among the available commercial models [12], is selected to perform the continuous simulations. Results of the simulations are synthesized through event and seasonal based performance indexes in order to assess the role of ET.

\subsection{The Hydrologic Modelling}

The continuous simulation of the hydrologic response of a selected urban catchment is undertaken using SWMM v. 5.1.011 [13]. SWMM allows the simulation of the hydrologic and hydraulic processes at a sub-hourly time resolution. The urban catchment consists of a collection of subcatchment areas that receive rainfall and generate different hydrologic components including surface runoff, infiltration and evapotranspiration. Each subcatchment area should be characterized by single land-use type and homogenous properties in order to reliably simulate the catchment hydrologic response [14].

Concerning the green roof systems, the LID control module is implemented [4]. In the SWMM continuous simulations, a daily time series of potential evapotranspiration (PET) values is assigned in order to model the restoration of green roof retention capacity. The 1985 Hargreaves equation [15] is used in this study to compute daily PET values. The Hargreaves equation is a temperature-based 
equation that suitably reproduces the PET in case of green roof applications, even if it requires limited input data [16].

SWMM reproduces the actual ET rate as a constant proportion of PET (e.g., [2]) instead of modelling the reduced levels of actual ET that are known to arise when substrate moisture availability becomes restricted $[9,17]$. However, fundamentally in the continuous simulations, the prediction of ET needs to be advanced with more physically-based parameters [18]. In this study, a new methodology to estimate suitably the role of actual evapotranspiration in continuous simulation performed with SWMM is presented.

\section{The Actual Evapotranspiration}

As the water available for ET decreases with time during the dry periods, directly using the PET rates will overestimate the actual ET (e.g., $[8,19])$. If it is assumed that ET rates during the wet periods would be equal to the PET rates, then on a monthly basis, only the dry periods determine how far actual ET rates fall below the PET rates [17].

In order to revise the ET rates, the following methodology is proposed: first, the dry periods in each month are identified from the daily rainfall data; then the average actual ET rates during the dry periods are calculated by assuming a direct evapotranspiration, limited just by the water supply conditions [20], and finally a monthly correction factor is evaluated. Note that the dry periods are evaluated in days and are defined as continuous series of dry days for which the observed daily rainfall depth is less than $2 \mathrm{~mm}$.

The monthly correction factor, $k$, is calculated by combining the wet period PET rates with the dry period actual ET rates according to the following equation by Peng and Stovin [17]:

$$
k=\frac{\beta+\frac{1}{2} \cdot \sum_{1}^{x} n(1+\alpha)}{D}
$$

where $\beta$ represents the wet days in the month; $x$ is the number of continuous dry periods in the month; $n$ is the duration of dry period (days); $\alpha$ is the actual ET rate at the end of the dry period (expressed as proportion of PET) and $D$ is the total number of days in the month (days).

The actual ET rate (expressed as a proportion of PET) at the end of the dry period, $\alpha$, is calculated as follows:

$$
\alpha=\frac{\mathrm{SMC}}{\mathrm{FC}}
$$

where SMC is the soil moisture at the end of the dry period and FC is the field capacity.

It follows that the daily actual ET rates are derived by multiplying the daily PET rates calculated from the Hargreaves equation with the corresponding monthly correction factor.

\subsection{The Site Description}

The urban catchment of Colle Ometti, in the town of Genoa (Italy), is selected as a test site for the hydrologic modelling of a green roof retrofitting scenario. Storm water runoff was monitored for both quantity and quality aspects in 2005 when the site was equipped with a technological station to measure on-site rainfall and flow rate data and to collect discrete runoff samples [21]. This 5 ha catchment was urbanised in the eighties with 500 houses built on a previously undeveloped hill slope. The management of storm water is addressed according to the traditional approach; in particular the separate sewer system consists of a main collector and eight lateral sewers, and with no LID source control solutions (green roofs) installed in the catchment.

As illustrated in Table 1, land uses are classified as rooftop, road and parking lot, green area and farmland; total impervious / pervious areas are calculated based on the regional cartography and aerial photographs. The analysis of land-use data reveals that $60 \%$ of the Colle Ometti catchment is covered with impervious surfaces and that rooftops account for $31 \%$ of the total area.

The installation of green roofs (for all rooftops of the catchment) is assumed here as a hypothetical retrofitting scenario according to a sustainable storm water mitigation strategy. Referring to the 
effective impervious area (EIA) that is defined as the impervious area directly connected to the storm drainage system [22], in the present study the EIA reduction corresponding to the green roof retrofitting scenario is equal to $31 \%$ of the catchment area.

The selected green roof system consists of a growing medium (total depth of $12 \mathrm{~cm}$ ) and a loose-laid synthetic specialized layer (drainage and filter layers for a total depth of $2.5 \mathrm{~cm}$ ) produced by Harpo Seic Verde Pensile (Trieste, Italy). Specific investigation of the water retention characteristics of the growing medium is reported in Savi et al. [23].

By considering long-term performance, the maintenance operation strategies adopted to maintain the LID system's permeability should be taken into account; however, the selection of green roofs as retrofitting scenario is suitable for assessing long-term performance since green roofs are less sensitive to clogging phenomena compared with other vegetated LID systems [24]. As for the irrigation, during the continuous simulations no irrigation cycles are foreseen in order to simply point out the role of ET in non-irrigated green roofs. The irrigation demand is a key factor characterizing the long-term efficiency and irrigated green roofs require further studies (e.g., [25]).

Table 1. Land-use characteristics of the urban catchment.

\begin{tabular}{ccc}
\hline \multirow{2}{*}{ Land Use } & \multicolumn{2}{c}{ Area } \\
\cline { 2 - 3 } & (ha) & (\%) \\
\hline Rooftop & 1.41 & 31 \\
Road and Parking Lot & 1.28 & 28 \\
Other impervious & 0.06 & 1 \\
\hline Total Impervious & 2.75 & 60 \\
\hline Green Area & 1.28 & 28 \\
Farmland & 0.53 & 12 \\
\hline Total Pervious & 1.81 & 40 \\
\hline Total Areas & 4.56 & 100 \\
\hline
\end{tabular}

The climatic regime of the study area is analysed based on rainfall and air temperature data collected at the nearby gauge station of Villa Cambiaso (44.3986 N; $8.9633 \mathrm{E})$ for the period from 1990 to 2015.

The rainfall data are available since 1990 with 1-min resolution. Throughout the investigated period, 1434 rainfall events are selected using a threshold filter able to extract events with total depth and antecedent dry weather period respectively exceeding $2.0 \mathrm{~mm}$ and $6 \mathrm{~h}$. Table 2 summarizes the rainfall characteristics for the time series climate records of Villa Cambiaso: the mean annual precipitation and the rainfall-event characteristics in terms of depth, duration, antecedent dry weather period (ADWP) and maximum intensity over $10 \mathrm{~min}$ are reported. The statistics of the annual rainfall depth as well as the rainfall-event characteristics are typical of the Mediterranean area: the average and standard deviation values of the annual rainfall depth are, respectively, $1340 \mathrm{~mm}$ and $372 \mathrm{~mm}$, the rainfall-event depth and ADWP are higher than $23 \mathrm{~mm}$ and 3 days, on average.

Table 2. Rainfall characteristics for the time series climate records (1990-2015) of Villa Cambiaso (Genoa, Italy). ADWP is the antecedent dry weather period and the maximum intensity is evaluated over $10 \mathrm{~min}$.

\begin{tabular}{cccccc}
\hline \multirow{2}{*}{ Statistical Data } & Annual Depth & Depth & Duration & ADWP & Max. Intensity \\
\cline { 2 - 6 } & $\mathbf{( m m )}$ & $\mathbf{( m m )}$ & $\mathbf{( h )}$ & $\mathbf{( d )}$ & $\mathbf{( m m} / \mathbf{h})$ \\
\hline Maximum & 2320 & 462.8 & 88 & 63 & 234 \\
Minimum & 714 & 2.2 & 0.1 & 0.3 & 0.8 \\
Mean & 1340 & 23.6 & 12 & 3.1 & 23 \\
Standard deviation & 372 & 37.3 & 12 & 4.6 & 28 \\
\hline
\end{tabular}


The air temperature data are available since 1990 with 30-min resolution. Throughout the investigated period, daily maximum and minimum temperature are calculated in order to properly estimate PET rates according to the Hargreaves equation.

\section{The Model Setting}

The study area in the current configuration ("do nothing scenario") is simplified in 286 subcatchments, 102 junctions and 101 conduits; this high-resolution discretization results in subcatchment areas characterized by single land-use type and homogenous properties. Consequently, in the retrofitting scenario the green roofs are applied to the selected subcatchments (all the rooftops) and occupy the full subcatchment area (i.e., roof surface is converted into green roof). The calibration parameters for the green roof system are reported in Table 3.

Table 3. Green roof parameters assigned in the Storm Water Management Model (SWMM)-low impact development (LID) control section.

\begin{tabular}{|c|c|c|c|c|c|c|}
\hline Layers & $\begin{array}{c}\text { Field } \\
\text { Capacity }\end{array}$ & $\begin{array}{l}\text { Wilting } \\
\text { Point }\end{array}$ & $\begin{array}{l}\text { Hydraulic } \\
\text { Conductivity }\end{array}$ & $\begin{array}{l}\text { Conductivity } \\
\text { Slope }\end{array}$ & Porosity & $\begin{array}{c}\text { Manning } \\
\text { Coefficient }\end{array}$ \\
\hline & $(-)$ & $(-)$ & $(\mathrm{mm} / \mathrm{h})$ & $(-)$ & $(-)$ & $\left(\mathrm{s} / \mathrm{m}^{1 / 3}\right)$ \\
\hline Soil & 0.43 & 0.07 & 1000 & 15 & 0.66 & - \\
\hline Drainage & - & - & - & - & 0.4 & 0.02 \\
\hline
\end{tabular}

The Soil Conservation Service Curve Number Method is used to estimate infiltration losses and runoff is calculated using Manning's equation. Curve Number $(\mathrm{CN})$ value equal to 98 is assumed for rooftops, roads and parking lots and other impervious areas while $\mathrm{CN}$ value equal to 70 is assumed for green areas; $n$-Manning value equal to 0.012 is assumed for the rooftops and other impervious area while n-Manning value equal to 0.015 is assumed for the conduits. As for the flow routing computation, the dynamic wave theory is used. A detailed description of the model schematization and calibration procedure is available elsewhere [4].

The continuous simulations are performed over 26-years at 1-min time interval; as for the initial condition of the green roof systems, the initial saturation is assumed equal to 0.38 corresponding to a SMC of 0.30 . As is well known in the literature [2,4], the initial condition affects the simulation results only for the first rainy days while its impact reveals negligible from the second dry period forward.

\subsection{The Performance Analysis}

At the single installation scale, one-minute simulation results are analysed by means of event and seasonal-based performance.

The seasonal-based performance is introduced in order to assess the capability to restore the retention capacity of green roofs according to the proposed actual ET module in the SWMM application. The seasonal-based performance is assessed through the volume retention index evaluated as the relative percentage difference between the cumulative rainfall and the green roof outflow volumes over an annual or seasonal basis. Referring to the seasonal basis evaluation, the following seasons are defined:

- the winter season refers to the months of January, February and March;

- the spring season refers to the months of April, May and June;

- the summer season refers to the months of July, August and September;

- the autumn season refers to the months of October, November and December.

The event based performance is assessed through two indexes: the peak and volume reduction rates, namely $P R$ and $V R$, respectively. For each rainfall event, the peak reduction is calculated as 
the relative percentage difference between the outflow peaks evaluated for the reference impervious rooftop and the green roof; the volume reduction is similarly evaluated.

Once the proposed methodology is calibrated at the single installation scale, the event-based performance indexes ( $P R$ and $V R$ ) are investigated for the catchment application. The configuration which corresponds to the "do nothing" scenario is assumed as the reference scenario in order to measure the impact of the green roofs retrofitting scenario.

Finally at the catchment site, in order to assess the behaviour of the event based performance indexes as a function of the rainfall event characteristics, rainfall events are classified based on the rainfall depth and the Antecedent Dry Weather Period on an event basis. In particular, five classes characterised by a constant frequency of approximately 0.2 are defined. The hydrologic performance is then statistically examined by means of a non-parametric distribution: with respect to each class of rainfall characteristics, the median and mean values as well as the different percentiles (5th, 10th, 25th, 75th, 90th and 95th) are evaluated.

\section{Results and Discussion}

Continuous simulations (26-year long) are performed at the both single installation and catchment scales including a green roof retrofitting scenario, as follows:

- Three simulations for the single installation scale:

- reference impervious roof;

- green roof according to the PET;

- green roof according to the calibrated actual ET;

- Two simulations for the catchment scale:

- Do nothing scenario according to the actual ET (calibrated for the single installation);

- Retrofitting scenario (including the green roof conversion of all rooftop areas) according to the actual ET (calibrated for the single installation).

The modelling results of the entire simulation period are evaluated and discussed in order to assess the impact of the actual ET on the hydrologic performance of the green roof at the single installation scale.

Secondly the continuous simulation results are evaluated and discussed for the test site in order to assess the hydrologic performance of the green roof retrofitting scenario at the catchment scale.

\subsection{The Local Assessment of the Actual Evapotranspiration (ET)}

In order to assess the local ET rates for the entire simulation period, a first simulation run is carried out at the green roof single installation scale. In particular a daily time series of PET values is assigned in SWMM. Secondly the proposed methodology is implemented in order to compute the monthly correction factor as follows:

1. the dry periods in each month are identified from the daily rainfall data;

2. the SMC value at the end of each dry period is derived by the SWMM LID report ;

3. the actual ET rate (expressed as proportion of PET) at the end of each dry period is determined as the ratio between the SMC and the field capacity values;

4. the correction factors are determined for each month by using Equation (1).

As an example, the detailed description of data used to calculate the monthly correction factor referred to 1999 is reported in Table 4. Table 5 reports the monthly correction factors (proportion of PET) calculated after Peng and Stovin [17] for the time series climate records (1990-2015) of Villa Cambiaso (Genoa, Italy). Subsequently the daily actual ET rates are evaluated by multiplying the daily PET rates calculated from the Hargreaves equation with the corresponding monthly correction 
factor. The annual average PET daily rate of the test site (Genoa, Italy) is evaluated as $2.3 \mathrm{~mm} / \mathrm{d}$ which tends to be higher than the one observed in other studies in the Nordic or humid environment [16]. The annual average actual ET daily rate decreases to $1.8 \mathrm{~mm} / \mathrm{d}$ confirming that in the Mediterranean area the ET process is more limited by water availability than by the energy availability.

In Figure 1, the mean and the corresponding standard deviation values of the monthly rainfall depth with the daily temperature and evapotranspiration values with respect to each month are reported together for the time series climate records of Villa Cambiaso (Genoa, Italy). Note that grey dots indicate the potential evapotranspiration values while the white dots indicate the actual evapotranspiration values. Figure 2 illustrates the cumulative potential (grey dots) and actual (white dots) evapotranspiration rates with respect to each season and the corresponding cumulative rainfall depth for the time series climate records of Genoa.
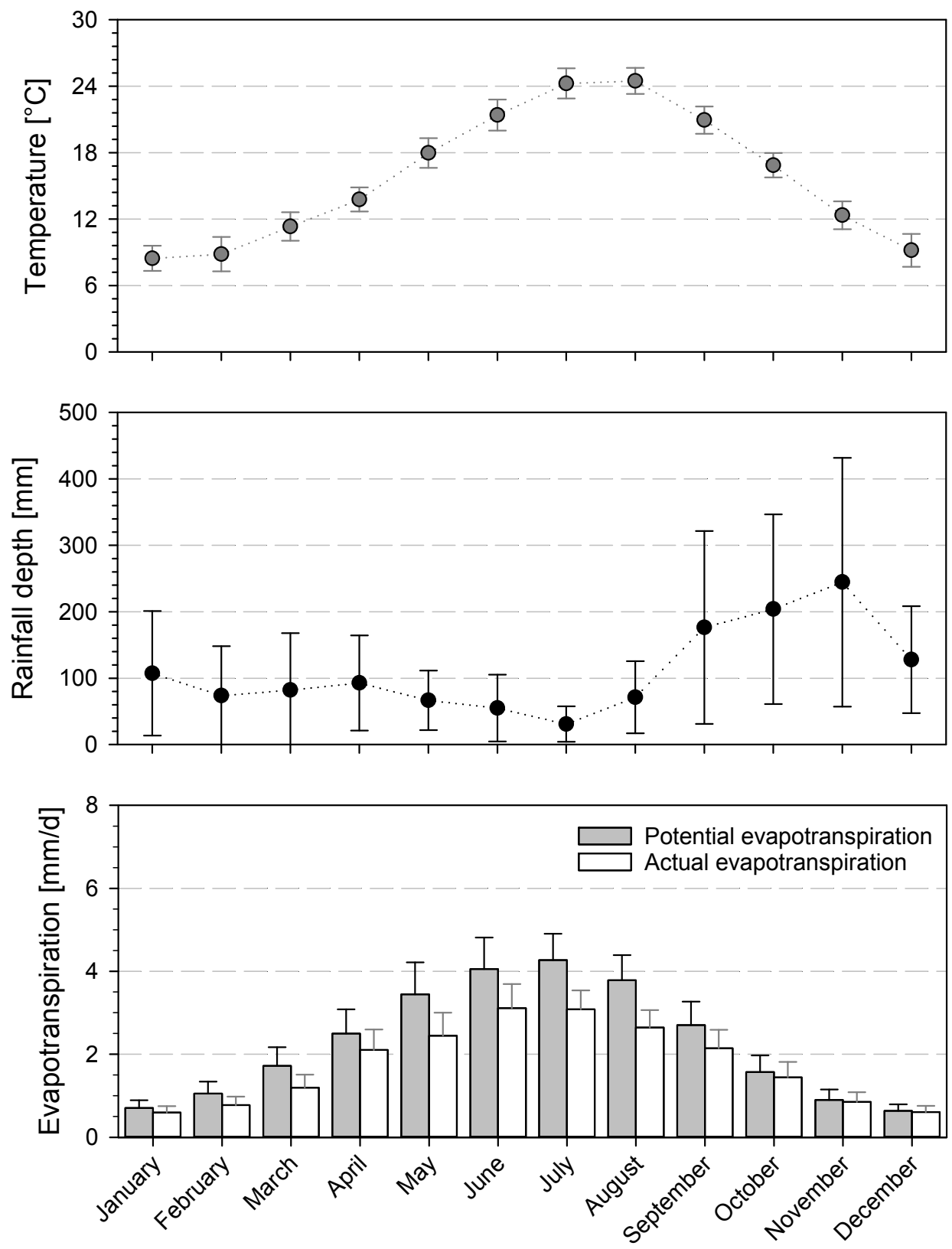

Figure 1. Daily temperature, monthly rainfall depth, potential and actual evapotranspiration for the time series climate records (1990-2015) of Villa Cambiaso (Genoa, Italy). The mean and the corresponding standard deviation values are reported. 



Figure 2. Seasonal evapotranspiration and rainfall depth for the time series climate records (1990-2015) of Villa Cambiaso (Genoa, Italy). The grey dots indicate the potential evapotranspiration and the white dots the actual evapotranspiration. 
Table 4. Monthly correction factors calculated after Peng and Stovin [18]. Soil moisture content and evapotranspiration (ET) rates (proportion of potential evapotranspiration (PET)) are evaluated at the end of the dry period; the reported data are referred to the 1999 year of the Villa Cambiaso (Genoa, Italy) time series climate records.

\begin{tabular}{|c|c|c|c|c|}
\hline Month & Continuous Dry Period & Soil Moisture Content ${ }^{1}$ & ET Rates ${ }^{1}$ & Correction Factor \\
\hline & (days) & $(-)$ & $(-)$ & $(-)$ \\
\hline \multirow[t]{3}{*}{ January } & 4 & 0.401 & 0.93 & 0.97 \\
\hline & 6 & 0.395 & 0.92 & \\
\hline & 7 & 0.354 & 0.82 & \\
\hline \multirow[t]{2}{*}{ February } & 15 & 0.199 & 0.46 & 0.68 \\
\hline & 12 & 0.072 & 0.17 & \\
\hline \multirow[t]{3}{*}{ March } & 3 & 0.26 & 0.60 & 0.81 \\
\hline & 11 & 0.072 & 0.17 & \\
\hline & 2 & 0.072 & 0.17 & \\
\hline \multirow[t]{6}{*}{ April } & 9 & 0.232 & 0.54 & 0.80 \\
\hline & 7 & 0.203 & 0.47 & \\
\hline & 3 & 0.258 & 0.60 & \\
\hline & 2 & 0.275 & 0.64 & \\
\hline & 2 & 0.219 & 0.51 & \\
\hline & 2 & 0.166 & 0.39 & \\
\hline \multirow[t]{3}{*}{ May } & 3 & 0.079 & 0.18 & 0.63 \\
\hline & 7 & 0.072 & 0.17 & \\
\hline & 18 & 0.073 & 0.17 & \\
\hline \multirow{4}{*}{ June } & 2 & 0.072 & 0.17 & 0.79 \\
\hline & 4 & 0.072 & 0.17 & \\
\hline & 3 & 0.072 & 0.17 & \\
\hline & 6 & 0.072 & 0.17 & \\
\hline \multirow[t]{2}{*}{ July } & 9 & 0.075 & 0.17 & 0.71 \\
\hline & 13 & 0.072 & 0.17 & \\
\hline \multirow[t]{6}{*}{ August } & 2 & 0.223 & 0.52 & 0.74 \\
\hline & 7 & 0.072 & 0.17 & \\
\hline & 2 & 0.335 & 0.78 & \\
\hline & 3 & 0.245 & 0.57 & \\
\hline & 6 & 0.072 & 0.17 & \\
\hline & 3 & 0.072 & 0.17 & \\
\hline \multirow[t]{3}{*}{ September } & 3 & 0.072 & 0.17 & 0.89 \\
\hline & 4 & 0.072 & 0.17 & \\
\hline & 3 & 0.361 & 0.84 & \\
\hline \multirow[t]{3}{*}{ October } & 4 & 0.319 & 0.74 & 0.92 \\
\hline & 5 & 0.221 & 0.51 & \\
\hline & 7 & 0.343 & 0.80 & \\
\hline November & 6 & 0.378 & 0.88 & 0.99 \\
\hline \multirow{4}{*}{ December } & 16 & 0.317 & 0.74 & 0.92 \\
\hline & 4 & 0.401 & 0.93 & \\
\hline & 2 & 0.388 & 0.90 & \\
\hline & 3 & 0.411 & 0.96 & \\
\hline
\end{tabular}

Results plotted in Figures 1 and 2 reveal that during the winter and autumn seasons the actual ET rates are almost equal to the PET rates. Indeed, such months correspond to the coldest and rainy periods where the impact of the evapotranspiration process is limited as confirmed by the mean value of cumulative PET ranging between 62 and $79 \mathrm{~mm}$ for autumn and winter, respectively. On the contrary, during spring and summer seasons where the temperature increases together with the decrease in rainfall depth, the role of the evaporation in the hydrologic water balance arises thus the actual ET rates fall significantly below the PET rates due to the limited availability of soil water content. 
Table 5. Monthly correction factors calculated after Peng and Stovin [18] for the time series climate records (1990-2015) of Villa Cambiaso (Genoa, Italy).

\begin{tabular}{cc}
\hline Month & Correction Factor \\
\hline & $\mathbf{( - )}$ \\
\hline January & 0.84 \\
February & 0.73 \\
March & 0.69 \\
April & 0.84 \\
May & 0.71 \\
June & 0.77 \\
July & 0.72 \\
August & 0.70 \\
September & 0.79 \\
October & 0.92 \\
November & 0.94 \\
December & 0.96 \\
\hline
\end{tabular}

\subsection{The Impact of the Actual ET at the Single Installation Scale}

Simulation results performed using both the PET and the actual ET as daily input climate data are analysed and compared by means of the volume retention index in order to assess the impact of the actual ET on the hydrologic performance of the green roof.

Figure 3 illustrates the box plot of the volume retention rate resulting from continuous simulations assuming the potential (grey box) and actual (hatched box) evapotranspiration, respectively. The retention index is evaluated with respect to the four investigated seasons and on an annual basis. The solid and dashed lines within the box indicate the median and mean values, respectively.

With the aim of improving the simulation results' readability and providing a comprehensive characterization of the seasonal precipitation regime, Table 6 summarizes the rainfall event characteristics observed with respect to each season.

Looking at the distribution of the volume retention index on a seasonal basis reported in Figure 3, two different behaviours clearly emerge with respect to both simulation scenarios (using both the PET and the actual ET). In particular, the volume retention values higher than 0.6 are associated with the spring and summer seasons (both in terms of mean and median values) while the winter and mainly autumn seasons reveal limited volume retention performance with the mean and median values below 0.45 . Similarly to findings from other research studies (e.g., [26,27]), it can be noticed that the volume retention performance of the green roof are observed consistently higher in the warmer and drier months of the year, largely accounted for higher potential evapotranspiration.

Focusing on the spring and summer seasons and comparing the PET and actual ET simulation scenarios, results confirm that the impact of the actual ET in decreasing the green roof volume retention performance is limited in summer (see Figure 3). Indeed the summer season is characterised by the longest ADWP (see Table 6) thus allowing the green roof to restore the water-holding capacity in both simulation scenarios (PET and actual ET). Referring to the volume retention index values, the lower performance observed in summer compared to the spring season is ascribable to the rainfall event characteristics: the high-intensity and short-duration events occurring in summer (see Table 6) that are typical of the Mediterranean climate reduce the green roof retention capacity with respect to the rainfall events occurring in spring.

Concerning the autumn and winter seasons and comparing the PET and actual ET simulation scenarios, the impact of the actual ET is revealed to be negligible in the autumn (see Figure 3) where the rainfall events are characterized by the shortest ADWP and the highest rainfall depth (see Table 6). Note that such conditions as well as the mean daily temperature strongly limit the effect of the ET process. Although the amount of PET is small in winter (see Figure 2), the winter season performance decreases (as mean and median values) when evaluated on the actual ET due to the decreasing rainfall 
depth (as mean and standard deviation values) with respect to the autumn season. On the other hand, comparing the volume retention values associated with the autumn and winter seasons, the latter show higher retention performance since the rainfall depth significantly decreases in winter and at the same time the ADWP increases. Referring to the annual performance, the variability of the volume retention is reduced compared to the box plot on a seasonal basis and is fairly consistent with the autumn season results: it has to be noticed that more than $40 \%$ of annual rainfall depth, on average, occurs in the autumn season.

The aforementioned results highlight the influence of the precipitation regime on the green roof's performance: both the rainfall depth and the corresponding ADWP significantly affect the hydrologic performance. Therefore, the actual ET estimate is needed to suitably assess the hydrologic performance of LIDs.

Figure 4 illustrates the non-parametric distribution of the volume and peak reduction rates simulated assuming the potential (grey box) and actual (hatched box) evapotranspiration. Although the impact of the actual ET on the event-based performance is limited and mainly evident for the volume reduction index, the VR median value equal to 0.81 (when PET is accounted) falls to 0.57 when the actual ET is considered. Such behaviour of the median values is mainly ascribable to the decrease (in number) of rainfall events that produce zero runoff in the case of actual ET, thus confirming the role of the ET in restoring the water-holding capacity of vegetated LIDs. Results are consistent with the recommendation mentioned in a similar study by Feng and Burian [9] according to which the annual runoff could be underestimated since the current EPA SWMM does not reflect a realistic ET temporal pattern at the sub-daily scale and during the dry periods after rain events.

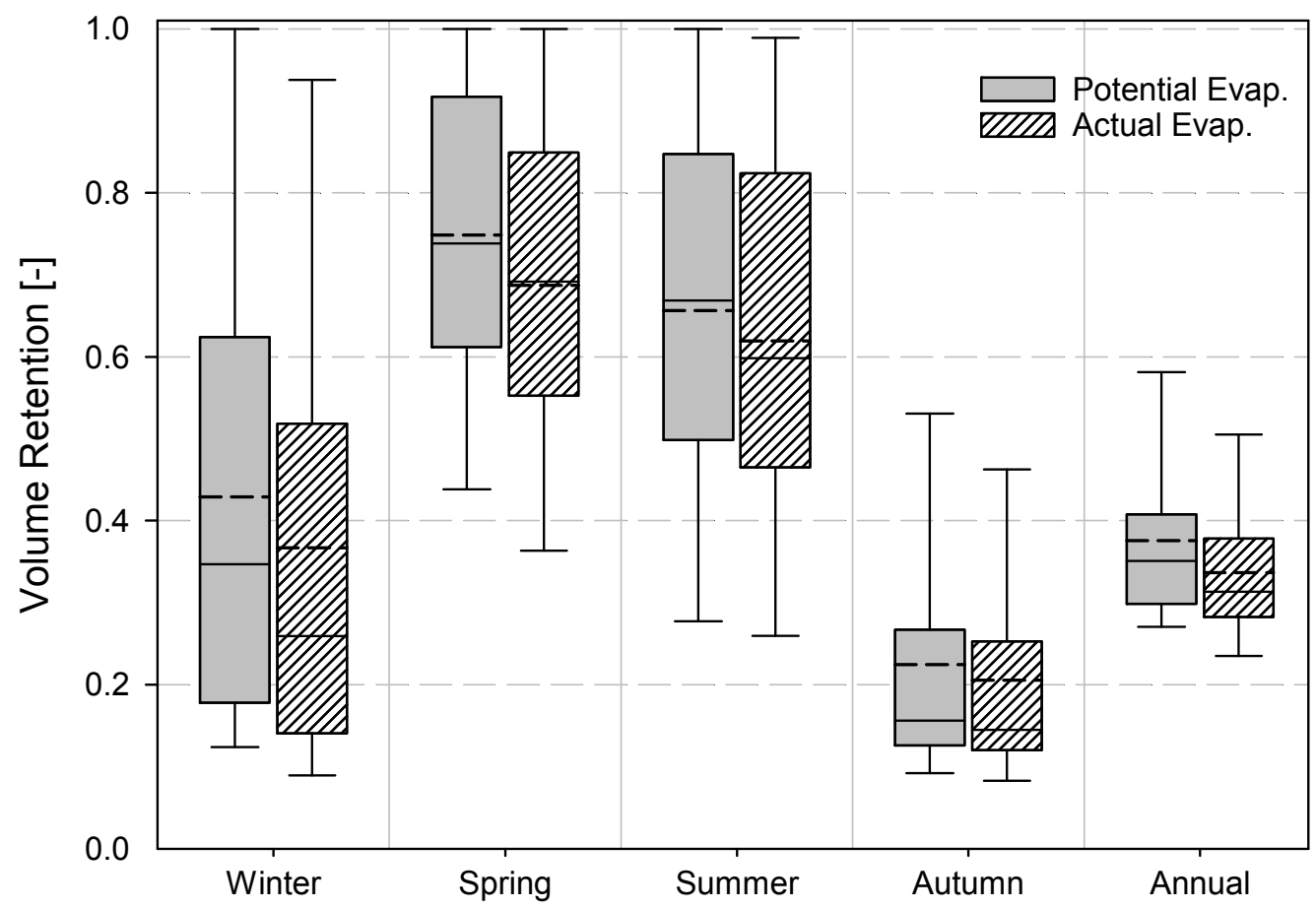

Figure 3. Non-parametric distribution of the volume retention rate simulated assuming the potential (grey box) and actual (hatched box) evapotranspiration on seasonal and annual basis at the single green roof scale. The solid and dashed lines within the box mark indicate the median and mean values, respectively. 
Table 6. Rainfall event characteristics (mean and standard deviation values) evaluated with respect to each season for the time series climate records (1990-2015) of Villa Cambiaso (Genoa, Italy). ADWP is the antecedent dry weather period and the maximum intensity is evaluated over $10 \mathrm{~min}$.

\begin{tabular}{cccccc}
\hline \multirow{2}{*}{ Season } & Cumulative Depth & Event Depth & Event Duration & ADWP & Max. Intensity \\
\cline { 2 - 6 } & $\mathbf{( m m )}$ & $\mathbf{( m m )}$ & $\mathbf{( h )}$ & $\mathbf{( d )}$ & $\mathbf{( m m} / \mathbf{h})$ \\
\hline Winter & $263.2 \pm 174.7$ & $10.9 \pm 19.9$ & $8.2 \pm 11.1$ & $3 \pm 6$ & $7.5 \pm 12.6$ \\
Spring & $214.6 \pm 84.1$ & $8 \pm 14.8$ & $5.5 \pm 8.9$ & $3 \pm 4$ & $10.4 \pm 17.8$ \\
Summer & $278.6 \pm 152.8$ & $12.8 \pm 33.2$ & $4.4 \pm 6.7$ & $4 \pm 6$ & $20.7 \pm 31.1$ \\
Autumn & $576.4 \pm 278.9$ & $18.6 \pm 39.7$ & $9.1 \pm 12.9$ & $2 \pm 3.5$ & $14.6 \pm 23.7$ \\
\hline
\end{tabular}

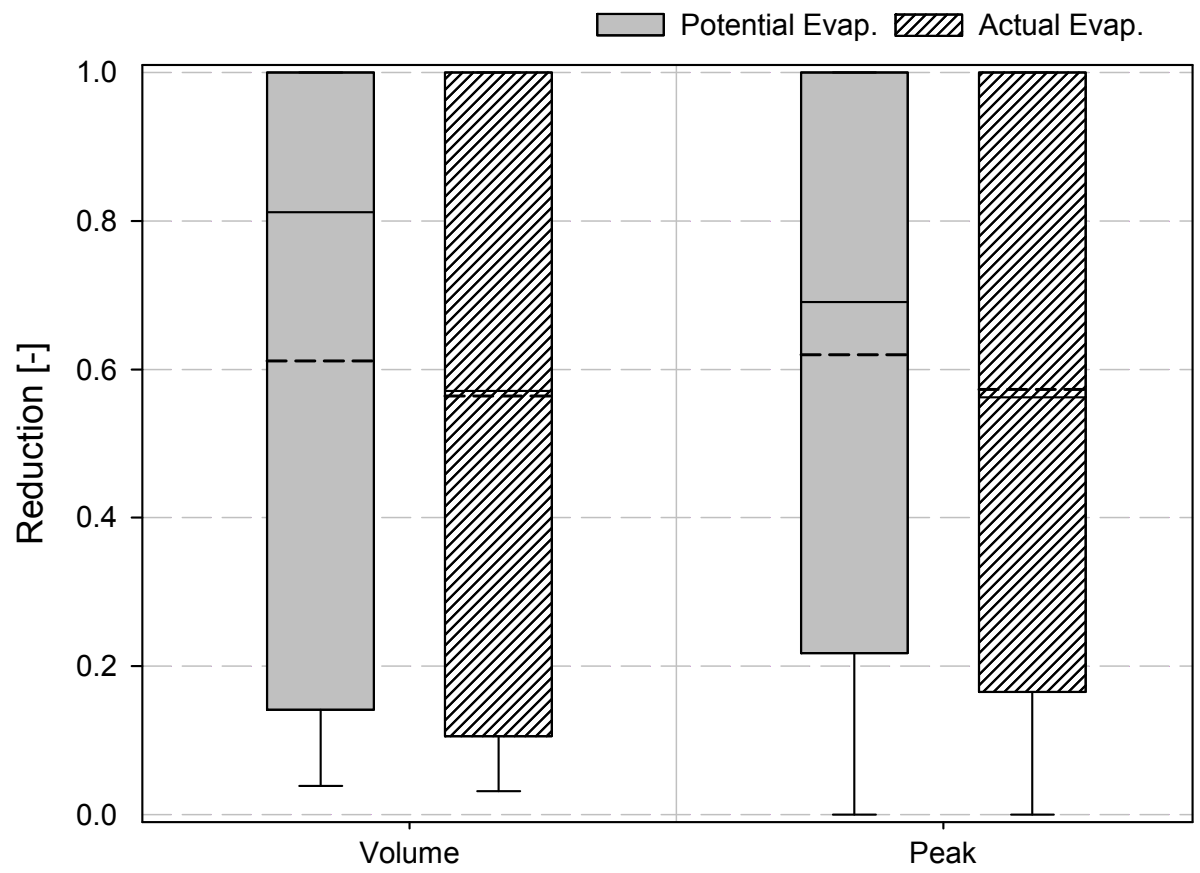

Figure 4. Non-parametric distribution of the volume and peak reduction rates simulated assuming the potential (grey box) and actual (hatched box) evapotranspiration at the single green roof scale. The solid and dashed lines within the box mark indicate the median and mean values, respectively.

\subsection{The Event-Based Performance at the Catchment Scale}

As for the catchment scale analysis, the continuous simulation (26-year long) is performed using the actual ET input data series. Note that the actual ET input data are derived for the time series climate records of Villa Cambiaso and calibrated for the green roof system selected in the present study (see Figures 2 and 3). As previously stated in the literature, the relationship between PET and ET is siteand plant-specific [28], however the proposed methodology can be replicated easily for other locations and green roofs only requiring daily weather data and green roof parameters (e.g., field capacity). Simulation results provide a full characterization of the hydrologic performance of the investigated catchment including the retrofitting scenario at 1-min time resolution. The continuous simulation investigates the impact of green roof retrofitting scenarios on the hydrologic performance by means of the analysis of a significant number of observed rainfall events characterized by different rainfall depths, durations, antecedent dry weather periods and return periods. This event per event analysis including its intrinsic initial soil moisture condition should complete the previous investigations related to single rainfall events at a given return period [4].

Based on the simulation results, it emerges that the values of peak and volume reduction rates, evaluated for the 1434 rainfall events are, respectively, equal to 0.3 on average, while the 
maximum values are 0.96 for peak and 0.86 for volume. Simulation results fully support the notion that the LID retrofitting effectively affects the hydrologic performance at the catchment scale although the widespread implementation of these systems strongly affects the performance. In this specific application, the maximum value of volume reduction is limited to 0.86 since the effective impervious area reduction is limited to $31 \%$ of the total catchment area.

Pointing out the influence of the precipitation regime, the 1434 rainfall events are classified based on the following characteristics on an event basis: the rainfall depth and the ADWP. In particular, the performance is discussed according to the five classes of rainfall depth and ADWP, characterized by a constant frequency of about 0.2 . Several authors have tried to provide a context for how ADWP, storm size, and PET relate individually to green roof hydrologic performance (e.g., [29,30]); however, the understanding of the factors that contribute to the performance variability is still an open question [31].

Figures 5 and 6 show respectively the non-parametric distribution of the volume (hatched box) and peak (grey box) reduction rates for each class of the rainfall depth and ADWP. Results plotted in Figure 5 confirm that the total rainfall depth significantly affects the hydrologic performance. The median values of the both reduction indexes range between 0.38 and 0.61 for rainfall depth lower than $16 \mathrm{~mm}$, while rapidly decreasing when the rainfall depth exceeds $32 \mathrm{~mm}$. Looking at data reported in Figure 6, it clearly emerges that the ADWP affects the hydrologic performance of a retrofitted LID catchment. Consistent with literature results, the hydrologic performance increases with longer ADWP (e.g., [31]); in particular, when the ADWP is below $48 \mathrm{~h}$ both the peak and volume reduction rates are fairly constant both in terms of mean values and range of variation while the hydrologic performance increases with ADWP longer than $48 \mathrm{~h}$. Furthermore, it can be noticed that ADWP values longer than 5 days $(120 \mathrm{~h})$ not only reveal that the highest performance is equal to 0.49 for peak and 0.46 for volume on average, but that the interquartile range significantly decreases for this ADWP class: $V R$ ranges from 0.37 to 0.58 and $P R$ from 0.42 to 0.62 .

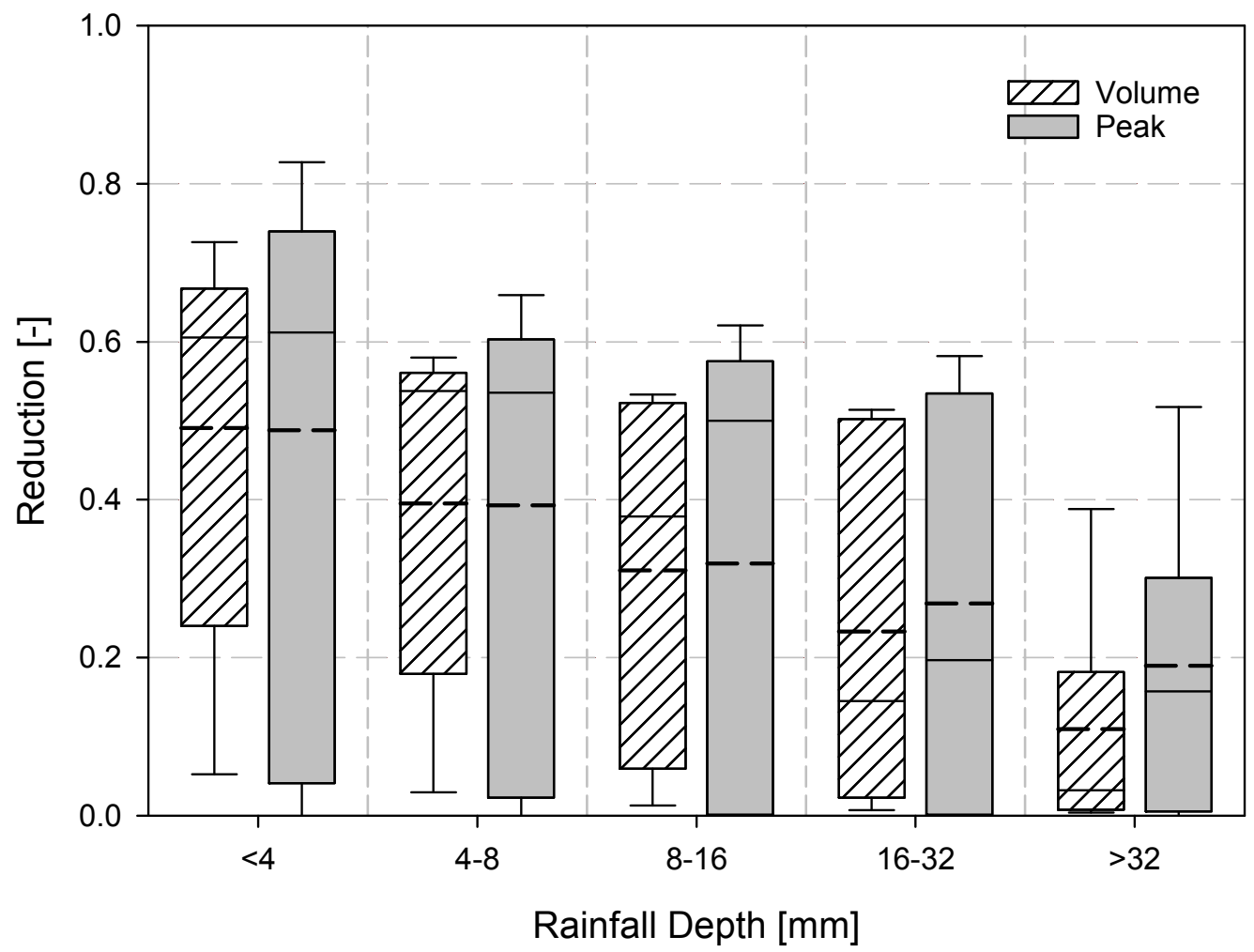

Figure 5. Non-parametric distribution of the volume (hatched box) and peak (grey box) reduction rates simulated at the catchment scale for each class of the rainfall depth. The solid and dashed lines within the box mark indicate the median and mean values respectively. 


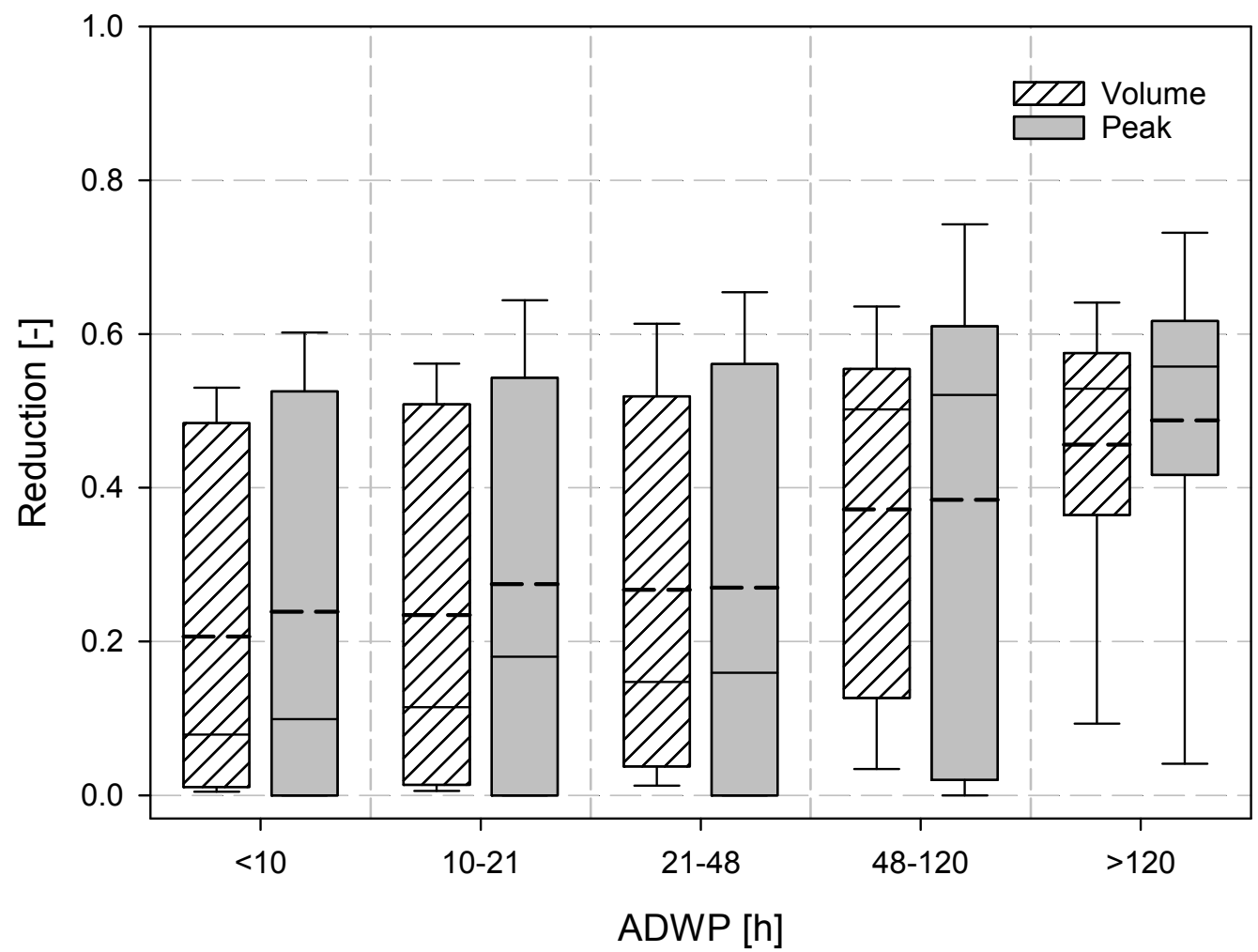

Figure 6. Non-parametric distribution of the volume (hatched box) and peak (grey box) reduction rates simulated at the catchment scale for each class of the ADWP. The solid and dashed lines within the box mark indicate the median and mean values respectively.

Such results highlight the role of the ET during the dry period between two subsequent rainfall events (ADWP) in affecting the initial moisture conditions at the beginning of the next rainfall event. Similarly to Elliot et al. [31], the findings of the present study suggest that further work could be undertaken to perform a bi-variate analysis in terms of both the ADWP and the rainfall depth in order to account for the extent to which the previous rainfall event saturated or not the substrate.

\section{Conclusions}

The present study analyses the hydrologic performance of a green roof retrofitting scenario at the catchment scale. The original contribution of the present study is related to the performance analysis that involves continuous simulations over a long-lasting series of observed climate data (at least 20 -years of precipitation and temperature records). Note that for the rainfall data, a high-resolution time scale is required to properly assess the hydrologic performance.

The continuous simulations of the selected green roof retrofitting scenario have been implemented in SWMM for which a simple methodological approach has been developed to evaluate the actual ET based on simple and easily accessible climate data. The actual ET methodology has been calibrated for a selected extensive green roof but it can be easily replicated for other vegetated LID applications. Furthermore, the ET monthly correction factors calculated for the time series climate records (1990-2015) of Villa Cambiaso (Genoa, Italy) could be used for similar LID systems and climates.

At the single installation scale, simulation results confirm the suitability of the proposed methodology to assess the role of the actual ET on restoring the water-holding capacity of vegetated LIDs. The impact of the actual ET on the hydrologic performance is limited and mainly evident for the volume reduction indexes; however, on a statistical basis the use of actual ET instead of PET is needed in order to not overestimate the performance. 
At the catchment scale, findings of the present study point out that LID retrofitting can significantly contribute to improve storm water runoff management in densely urbanised areas. As for the case study concerned, the hydrologic performance of the retrofitted urban catchment significantly increases when the ADWP is longer than 5 days. Furthermore, retrofitted green roofs still have an impact on the hydrologic response for rainfall events with a total depth greater than $32 \mathrm{~mm}$.

A limitation of this study is the lack of experimental data on the measure of actual ET for the validation of the methodological approach; the use of observational data for several green roof installations may lead to a generalization of the approach and, consequently, a definition of an easily accessible database of monthly correction factors for various climatic regions and vegetated system typologies. Furthermore, irrigation activities should be included in the proposed methodology since in dry climates, irrigation will modify the water supply conditions by increasing both ET and outflow volumes. Therefore, additional modelling work is required to include these considerations in the proposed scheme that, at the present time, is simply based on the analysis of the dry periods.

Although the impact of green roofs on runoff quality is still an open debate [32], the retention capacity of green roofs contributes to limit the runoff volume discharge into the receiving water body and, thus, the pollutant mass delivery associated with storm water runoff. In light of such considerations, it is reasonable to assume that the widespread use of vegetated LID systems at the urban catchment scale positively affects the quali-quantity aspects of urban water management.

Author Contributions: All authors contributed equally to conceiving and designing the methodological approach; and secondly, to analysing and discussing the results. Finally, all authors wrote and revised the paper.

Funding: This research received no external funding.

Conflicts of Interest: The authors declare no conflict of interest.

\section{References}

1. Ahiablame, L.M.; Engel, B.A.; Chaubey, I. Effectiveness of low impact development practices: Literature review and suggestions for future research. Water Air Soil Pollut. 2012, 223, 4253-4273. [CrossRef]

2. Cipolla, S.S.; Maglionico, M.; Stojkov, I. A long-term hydrological modelling of an extensive green roof by means of SWMM. J. Ecol. Eng. 2016, 95, 876-887. [CrossRef]

3. Bliss, D.J.; Neufeld, R.D.; Ries, R.J. Storm Water Runoff Mitigation Using a Green Roof. Environ. Eng. Sci. 2009, 26, 407-418. [CrossRef]

4. Palla, A.; Gnecco, I. Hydrologic modeling of Low Impact Development systems at the urban catchment scale. J. Hydrol. 2015, 528, 361-368. [CrossRef]

5. Loperfido, J.V.; Noe, G.B.; Jarnagin, S.T.; Hogan, D.M. Effects of distributed and centralized stormwater best management practices and land cover on urban stream hydrology at the catchment scale. J. Hydrol. 2014, 519, 2584-2595. [CrossRef]

6. Rosa, D.J.; Clausen, J.C.; Dietz, M.E. Calibration and verification of SWMM for Low Impact Development. J. Am. Water Resour. Assoc. 2015, 51, 746-757. [CrossRef]

7. Burszta-Adamiak, E.A.; Mrowiec, M. Modelling of green roofs' hydrologic performance using EPA's SWMM. Water Sci. Technol. 2013, 68, 36-42. [CrossRef] [PubMed]

8. Poë, S.; Stovin, V.; Berretta, C. Parameters influencing the regeneration of a green roof's retention capacity via evapotranspiration. J. Hydrol. 2015, 523, 356-367. [CrossRef]

9. Feng, Y.; Burian, S. Improving evapotranspiration mechanism in the U.S. environmental protection agency's Storm Water Management Model. J. Hydrol. Eng. 2016, 21, 06016007. [CrossRef]

10. Palla, A.; Gnecco, I.; La Barbera, P. The impact of domestic rainwater harvesting systems in storm water runoff mitigation at the urban block scale. J. Environ. Manag. 2017, 191, 297-305. [CrossRef] [PubMed]

11. Sims, A.W.; Robinson, C.E.; Smart, C.C.; Voogt, J.A.; Hay, G.J.; Lundholm, J.T.; Powers, B.; O'Carroll, D.M. Retention performance of green roofs in three different climate regions. J. Hydrol. 2016, 542, 115-124. [CrossRef]

12. Li, Y.; Babcock, R. Green roof hydrologic performance and modeling: A review. Water Sci. Technol. 2014, 69, 727-738. [CrossRef] [PubMed] 
13. Rossman, L.A. Storm Water Management Model User's Manual Version 5.0; EPA/600/R-05/040; US EPA National Risk Management Research Laboratory: Cincinnati, OH, USA, 2010.

14. Krebs, G.; Kokkonen, T.; Valtanen, M.; Setälä, H.; Koivusalo, H. Spatial resolution considerations for urban hydrological modelling. J. Hydrol. 2014, 512, 482-497. [CrossRef]

15. Hargreaves, G.H.; Samani, Z.A. Reference crop evapotranspiration from ambient air temperature. Appl. Eng. Agric. 1985, 1-2, 96-99. [CrossRef]

16. Berretta, C.; Poë, S.; Stovin, V. Moisture content behaviour in extensive green roofs during dry periods: The influence of vegetation and substrate characteristics. J. Hydrol. 2014, 511, 374-386. [CrossRef]

17. Peng, Z.; Stovin, V. Independent validation of the SWMM green roof module. J. Hydrol. Eng. 2017, 22, 04017037. [CrossRef]

18. Feng, Y.; Burian, S.J.; Pardyjak, E.R. Observation and estimation of evapotranspiration from an irrigatedgreen roof in a rain-scarce environment. Water 2018, 10, 262. [CrossRef]

19. Stovin, V.; Poë, S.; Berretta, C. A modelling study of long term green roof retention performance. J. Environ. Manag. 2013, 131, 206-215. [CrossRef] [PubMed]

20. Zhao, L.; Xia, J.; Xu, C.-Y.; Wang, Z.; Sobkowiak, L.; Long, C. Evapotranspiration estimation methods in hydrological models. J. Geogr. Sci. 2013, 23, 359-369. [CrossRef]

21. Palla, A. Unsaturated Flow in Engineered Porous Media for Hydrologic Restoration. Ph.D. Thesis, Department of Civil, Environmental and Architectural Engineering, University of Genoa, Genoa, Italy, 16 April 2009.

22. Shuster, W.D.; Bonta, J.; Thurston, H.; Warnemuende, E.; Smith, D.R. Impacts of impervious surface on watershed hydrology: A review. Urban Water J. 2005, 2, 263-275. [CrossRef]

23. Savi, T.; Andri, S.; Nardini, A. Impact of different green roof layering on plant water status and drought survival. Ecol. Eng. 2013, 57, 188-196. [CrossRef]

24. Brown, R.A.; Borst, M. Evaluation of surface and subsurface processes in permeable pavement infiltration trenches. J. Hydrol. Eng. 2015, 20, 04014041. [CrossRef]

25. Liu, Y.; Engel, B.A.; Flanagan, D.C.; Gitau, M.W.; McMillan, S.K.; Chaubey, I. A review on effectiveness of best management practices in improving hydrology and water quality: Needs and opportunities. Sci. Total Environ. 2017, 601, 580-593. [CrossRef] [PubMed]

26. Mentens, J.; Raes, D.; Hermy, M. Green roofs as a tool for solving the rainwater runoff problem in the urbanized 21st century? Landsc. Urban Plan. 2006, 77, 217-226. [CrossRef]

27. Marasco, D.E.; Hunter, B.N.; Culligan, P.J.; Gaffin, S.R.; McGillis, W.R. Quantifying evapotranspiration from urban green roofs: A comparison of chamber measurements with commonly used predictive methods. Environ. Sci. Technol. 2014, 48, 10273-10281. [CrossRef] [PubMed]

28. Voyde, E.; Fassman, E.; Simcock, R.; Wells, J. Quantifying evapotranspiration rates for New Zealand Green Roofs. J. Hydrol. Eng. 2010, 15, 395-403. [CrossRef]

29. Stovin, V.; Vesuviano, G.; Kasmin, H. The hydrological performance of a green roof test bed under UK climatic conditions. J. Hydrol. 2012, 414, 148-161. [CrossRef]

30. Wong, G.K.L.; Jim, C.Y. Quantitative hydrologic performance of extensive green roof under humid-tropical rainfall regime. Ecol. Eng. 2014, 70, 366-378. [CrossRef]

31. Elliott, R.M.; Gibson, R.A.; Carson, T.B.; Marasco, D.E.; Culligan, P.J.; McGillis, W.R. Green roof seasonal variation: Comparison of the hydrologic behavior of a thick and a thin extensive system in New York City. Environ. Res. Lett. 2016, 11, 074020. [CrossRef]

32. Gnecco, I.; Palla, A.; Lanza, L.G.; La Barbera, P. The role of green roofs as a source/sink of pollutants in storm water outflows. Water Res. Manag. 2013, 27, 4715-4730. [CrossRef]

(C) 2018 by the authors. Licensee MDPI, Basel, Switzerland. This article is an open access article distributed under the terms and conditions of the Creative Commons Attribution (CC BY) license (http:/ / creativecommons.org/licenses/by/4.0/). 